\title{
Congenital heart disease in Nigeria
}

\section{Clinical and necropsy study of 260 cases}

\author{
ASUQUO U. ANTIA \\ From the Department of Paediatrics, University College Hospital, Ibadan
}

\begin{abstract}
Antia, A. U. (1974). Archives of Disease in Childhood, 49, 36. Congenital heart disease in Nigeria: clinical and necropsy study of 260 cases. The present study of 260 combined necropsy and clinical cases of congenital heart defect has revealed that the various types of defects occur in the same proportions in Africans as in non-Africans. The frequency of associated noncardiac malformations, the cause of death, and sex distribution are similar to what has been described in non-Africans. Of the possible aetiological factors, there was evidence of a causal relation between maternal rubella infection and persistent ductus arteriosus. There was, bowever, no such evidence in respect of abnormal haemoglobins, maternal age, and birth rank.
\end{abstract}

In a previous necropsy study of 47 cases of congenital heart disease in Nigeria, Antia and Williams (1971) showed that most of the congenital heart malformations seen elsewhere seemed to occur in Nigeria. Though the number of cases studied then was relatively small, the incidence of the different types of defects and associated noncardiac malformations appeared to be the same as in Caucasians.

The purpose of the present study was (a) to describe the various types of congenital heart disease (necropsy and clinical cases) studied over a period of 5 years (January 1965 to January 1970) in indigenous African children from birth to the age of 14 years; (b) to examine possible aetiological factors, causes of death, and associated noncardiac malformations in congenital heart disease as seen in an institution in Nigeria.

\section{Subjects and methods}

The subjects and methods of the necropsy study have been described elsewhere (Antia and Williams, 1971). Since then, 6 more necropsy materials have been studied. Briefly, the necropsy records of the Department of Pathology at the University College Hospital, Ibadan, were examined and all congenital cardiovascular abnormalities for a period were abstracted. A few cases were excluded because they were either probe-persistent foramen ovale or persistent ductus arteriosus in perinatal deaths unassociated with other cardiac malformations.

All the patients studied during life were examined by the author. A cardiac register was established in the

Received 10 July 1973.
Department of Paediatrics in July 1966, and all types of heart disease in children from birth to the age of 12 years (a few cases above 12 years have also been studied) are entered into this register. In the period of the present study, congenital heart disease constituted about $70 \%$ of all cardiac disorders in childhood. The diagnosis in each case was based on clinical examination, a 12-lead electrocardiogram (ECG), and chest $x$-rays with barium swallow. Selective angiocardiography was carried out in those cases in which a definite anatomical diagnosis could not be reached on the basis of clinical examination, ECG, and $x$-rays. Surgical treatment was performed on 20 of the cases (Bankole, Oduntan, and Antia, 1972). Other investigations included $\mathrm{Hb}$, packed red cell volume, $\mathrm{Hb}$ electrophoresis ( $\mathrm{Hb}$ genotype), height, weight, birth rank, maternal age, and socioeconomic factors.

\section{Results}

The total number of combined necropsy and clinical cases of congenital heart disease during the period of study was 260 (53 necropsy and 207 clinical cases). The various types of defect and their distribution are shown in Table I. It will be observed that ventricular septal defect was the commonest defect $(27 \%)$ in the series. The next common defect was persistent ductus arteriosus $(18 \%)$, followed by atrial septal defect $(14 \cdot 2 \%)$, pulmonary stenosis $(12.3 \%)$ and Fallot's tetralogy $(12 \cdot 3 \%)$. The miscellaneous and less common defects (Table II) constituted $16 \cdot 2 \%$ of the series comprising cases which have been described in non-African children.

There was no significant difference in the sex 
TABLE I

Types and distribution of congenital malformations of heart and great vessels in 260 Nigerian children

\begin{tabular}{l|c|c}
\hline \multicolumn{1}{c|}{ Type of malformation } & No. of cases & $\begin{array}{c}\text { Percentage } \\
\text { of total }\end{array}$ \\
\hline Ventricular septal defect & 70 & $27 \cdot 0$ \\
Persistent ductus arteriosus & 47 & $18 \cdot 0$ \\
Atrial septal defect & 37 & $14 \cdot 2$ \\
Pulmonary stenosis & 32 & $12 \cdot 3$ \\
Fallot's tetralogy & 32 & $12 \cdot 3$ \\
Miscellaneous & 42 & $16 \cdot 2$ \\
\hline Total & 260 & $100 \cdot 0$ \\
\hline
\end{tabular}

incidence (Table III) either in the series as a whole or in cases with ventricular septal defect and pulmonary stenosis. However, the male/female ratio was $1: 2$ in persistent ductus arteriosus and atrial septal defect, and $2 \cdot 2: 1$ in Fallot's tetralogy. There was one case of intersex.

\section{TABLE II}

Frequency of 42 miscellaneous types of congenital malformations of heart and great vessels in 260 Nigerian children

\begin{tabular}{|c|c|c|}
\hline Type of malformation & $\begin{array}{l}\text { No. of } \\
\text { cases }\end{array}$ & $\begin{array}{l}\text { Percentage } \\
\text { of } 260 \text { cases }\end{array}$ \\
\hline $\begin{array}{l}\text { Ebstein's malformation of tricuspid } \\
\text { valve } \\
\text { Congenital tricuspid incompetence* } \\
\text { Tricuspid atresia } \\
\text { Mitral atresia } \\
\text { Transposition of great arteries } \\
\text { Single ventricle } \\
\text { Aortic anomalies } \\
\text { Persistent left superior vena cava } \\
\text { draining into coronary sinus + } \\
\text { VSD + PDA } \\
\text { Persistent truncus + ASD } \\
\text { Origin of aorta from right } \\
\text { ventricle + VSD + accessory } 3 r d \\
\text { ventricle } \\
\text { A-V communis + pulmonary artery } \\
\text { atresia + aorta arising from right } \\
\text { ventricle } \\
\text { Coarctation of aorta } \\
\text { Anomalous venous return } \\
\text { Dextrocardia with or without situs } \\
\text { inversus } \\
\text { Right aortic arch with vascular ring } \\
\text { Coronary artery aneurysm } \\
\text { Undetermined cyanotic defect } \\
\text { Congenital heart block } \\
\text { Right pulmonary artery aneurysm }+ \\
\text { PDA + VSD + hypoplastic } \\
\text { ascending aortat }\end{array}$ & $\begin{array}{l}2 \\
3 \\
4 \\
4 \\
1 \\
2 \\
2 \\
3\end{array}$ & $\begin{array}{l}0 \cdot 4 \\
1 \cdot 2 \\
0 \cdot 4 \\
\\
0 \cdot 8 \\
1 \cdot 2 \\
1 \cdot 5 \\
1 \cdot 5 \\
0 \cdot 4 \\
0 \cdot 8 \\
0 \cdot 8 \\
1 \cdot 2 \\
0.4\end{array}$ \\
\hline Total & 42 & $16 \cdot 6$ \\
\hline
\end{tabular}

*Antia and Osunkoya (1969).

†Dawodu, Antia, and Lagundoye (1972).

VSD, ventricular septal defect; PDA, persistent ductus asteriosus ;

ASD, atrial septal defect.
TABLE III

Sex distribution in 260 Nigerian children with congenital malformations of heart and great vessels

\begin{tabular}{l|c|c|c}
\hline \multirow{2}{*}{ Type of malformation } & \multicolumn{2}{|c|}{ Sex $^{\star}$} & M/F ratio \\
\cline { 2 - 3 } & M & F & \\
\hline Ventricular septal defect & 29 & 41 & $1: 1 \cdot 4$ \\
Persistent ductus & 15 & 32 & $1: 2 \cdot 1$ \\
$\quad$ arteriosus & 12 & 25 & $1: 2 \cdot 6$ \\
Atrial septal defect & 15 & 17 & $1: 1 \cdot 1$ \\
Pulmonary stenosis & 22 & 10 & $2 \cdot 2: 1$ \\
Fallot's tetralogy & 26 & 15 & $1 \cdot 8: 1$ \\
Miscellaneous & 119 & 140 & $1: 1 \cdot 7$ \\
\hline Total & & & \\
\hline
\end{tabular}

^One case of intersex.

Of the 53 necropsy cases, a majority (66\%) died in the first year of life (Table IV). The cause of death in 45 of the cases are summarized in Table V. Bronchopneumonia and postoperative complications were the commonest causes of death.

Associated noncardiac malformations (Table VI) occurred in $39 \%$ of the necropsy cases and in less than $5 \%$ of the clinical cases. $41 \%$ of the malformations occurred in the alimentary tract. Skeletal malformations were present in a family with

\section{TABLE IV}

Age when death occurred in 53 cases of congenital malformations of heart and great vessels

\begin{tabular}{c|c|c}
\hline Age & No. of cases & $\begin{array}{c}\text { Percentage of } \\
\text { cases }\end{array}$ \\
\hline $0-4 \mathrm{wk}$ & 23 & $42 \cdot 6$ \\
$2-6 \mathrm{mth}$ & 11 & $19 \cdot 1$ \\
$7-11 \mathrm{mth}$ & 2 & $4 \cdot 3$ \\
$1-6 \mathrm{yr}$ & 13 & $25 \cdot 3$ \\
$7-10 \mathrm{yr}$ & 4 & $8 \cdot 3$ \\
\hline Total & 53 & $100 \cdot 0$ \\
\hline
\end{tabular}

TABLE V

Causes of death in 45 cases of congenital malformations of heart and great vessels

\begin{tabular}{l|c}
\multicolumn{1}{c|}{ Cause of death } & No. of cases \\
\hline Bronchopneumonia & 13 \\
Subacute bacterial endocarditis & 1 \\
Cerebral abscess & 4 \\
Heart failure & 4 \\
Stillbirth & 1 \\
Postoperative & 9 \\
Others & 13 \\
\hline Total & 45 \\
\hline
\end{tabular}


TABLE VI

Noncardiac congenital malformations associated with congenital heart defects

\begin{tabular}{|c|c|}
\hline System & Malformation \\
\hline CNS & $\begin{array}{l}\text { Microcephaly } \\
\text { Hydrocephaly } \\
\text { Occipital encephalocele }\end{array}$ \\
\hline Alimentary & $\begin{array}{l}\text { Imperforate anus } \\
\text { Tracheo-oesophageal } \\
\quad \text { fistula } \\
\text { Duodenal atresia } \\
\text { Exomphalos } \\
\text { Right-sided stomach } \\
\text { Cleft palate and lip }\end{array}$ \\
\hline Skeletal & $\begin{array}{l}\text { High arched palate } \\
\text { Talipes } \\
\text { Polydactyly } \\
\text { Syndactyly }\end{array}$ \\
\hline Genitourinary & $\begin{array}{l}\text { Bifid uterus } \\
\text { Polycystic kidneys } \\
\text { Bladder neck valves } \\
\text { Renal cysts }\end{array}$ \\
\hline Miscellaneous & $\begin{array}{l}\text { Inguinal herniae } \\
\text { Absent eyeballs } \\
\text { Gallbladder agenesis }\end{array}$ \\
\hline
\end{tabular}

Holt-Oram syndrome (Antia, 1970), and in one case of atrial septal defect with Ellis-van Creveld syndrome. Other malformations occurred with no significant frequency.

Of 41 patients with persistent ductus arteriosus studied during life, 9 had associated microophthalmos, congenital cataract, mental retardation etc., consistent with maternal rubella syndrome. It was possible to obtain the exact month of birth in

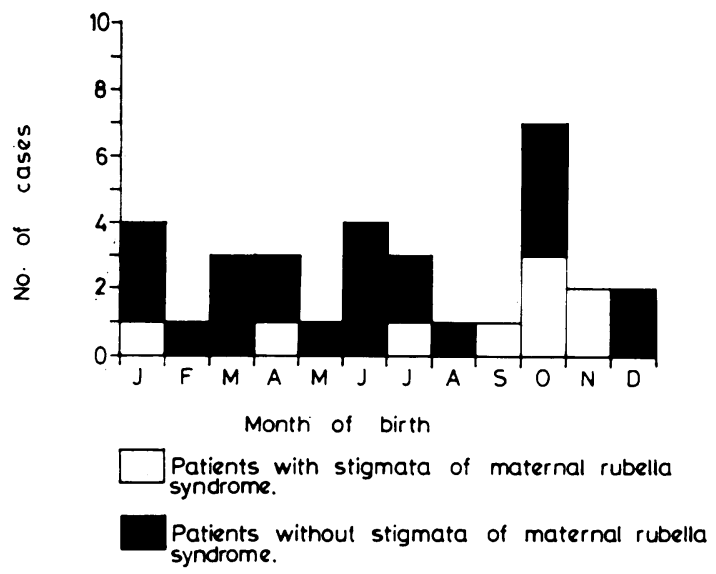

FIG.-Month of birth of 32 patients with persistent ductus arteriosus.
32 of the 41 patients (Fig.). $12(37.5 \%)$ of the 32 patients were born between September and November. Though the number studied is small, this finding suggests the occurrence of epidemics of maternal rubella infection in and around Ibadan between January and March in the period of the study.

$\mathrm{Hb}$ electrophoresis (genotype) was determined in 179 subjects and the distribution was $70.4 \% \mathrm{AA}$, $20 \cdot 1 \% \mathrm{AS}, 6 \cdot 1 \% \mathrm{AC}$, and $3.4 \%$ SS. Thus, there was no significant difference $\left(\chi^{2} 7 \cdot 32, P>0 \cdot 05\right)$ between this distribution of the genotypes and that in the general population. Nor was any particular cardiac defect associated with the genotypes in significant frequency.

Accurate maternal age at the time of birth of each subject was obtained from the mothers of 61 patients. 41 patients $(67 \cdot 2 \%)$ were born to mothers aged 20 to 29 years. Using as controls the maternal age of 1902 births at this hospital and of 3076 births at Igbo-Ora, a rural community near Ibadan, there was no significant difference $\left(\chi^{2}=9.47, P>0.05 ; \chi^{2}=11 \cdot 20, P>0.05\right.$, respectively) between the controls and the affected subjects. The birth rank of 130 patients also revealed no significant difference between the subjects and that of the control series obtained from births at the two hospitals $\left(\chi^{2}=11 \cdot 85, \mathrm{P}>0.025\right)$.

\section{Discussion}

The present study of combined necropsy and clinical materials defines more accurately than our previous study (Antia and Williams, 1971) the pattern of congenital heart disease in Nigerian children. The commonest isolated defect was ventricular septal defect constituting $27 \%$ of the series, followed by persistent ductus arteriosus $(18 \%)$, atrial septal defect $(14 \cdot 2 \%)$, and pulmonary stenosis $(12 \cdot 3 \%)$. Fallot's tetralogy was the commonest multiple defect comprising $12 \cdot 3 \%$ of the series. The frequency of the defects in this series compares closely with those reported by European and American authors (Wood, 1950; Keith, Rowe, and Vlad, 1958; Nadas, 1963; Blumenthal, 1954). Practically all the less common defects, including rare ones reported elsewhere, were found in the present study. Thus, it may be concluded that the pattern of congenital heart defect in Nigeria is the same as occurs elsewhere in the world.

The sexes were equal in the overall series, in keeping with findings elsewhere (Keith et al., 1958; Schrire, 1963). The significant preponderance of females over males with persistent ductus arteriosus 
and atrial septal defect in the present series has also been reported by others (Keith et al., 1958; Nadas, 1963; Wood, 1950; Schrire, 1963).

Associated noncardiac malformations occurred frequently in the present series and compared favourably with the findings by Abbott (1927), Gibson and Clifton (1938), MacMahon, McKeown, and Record (1953). Our experience with regard to age at death and causes of death is also similar to that reported elsewhere.

Of the possible aetiological factors there was evidence of an association between maternal rubella infection and persistent ductus arteriosus. This is of great clinical significance since it may be extremely difficult to make a diagnosis of maternal rubella infection in a person with a dark skin. The study further reveals that there may have been an epidemic of rubella infection in the first quarter of the year in Ibadan and its surroundings. There was no statistically significant evidence of any aetiological relation between congenital heart disease and abnormal $\mathrm{Hb}$, maternal age, and birth rank of the patients.

I thank Professor P. P. S. Nylander, Department of Obstetrics and Gynaecology, for data on birth rank and maternal ages of the controls; Mr. O. Ayeni, Department of Preventive and Social Medicine, for statistical analysis; and the Senate Research Grant Committee, University of Ibadan, for financial support.

\section{REFERENCES}

Abbott, M. E. (1927). Congenital heart disease. In Nelson Loose-Leaf Medicine, Vol. 4, p. 207. Ed. by W. W. Palmer. Nelson, New York.

Antia, A. U. (1970). Familial skeletal cardiovascular syndrome (Holt-Oram) in a polygamous African family. British Heart fournal, 32, 241.

Antia, A. U., and Osunkoya, B. O. (1969). Congenital tricuspid incompetence. British Heart fournal, 31, 664.

Antia, A. U., and Williams, A. O. (1971). Congenital heart disease in Nigeria. British Heart Fournal, 33, 133.

Bankole, M. A., Oduntan, S. A., and Antia, A. U. (1972). Experience with surgical treatment of congenital defects of the cardiovascular system in Nigeria. African fournal of Medical Sciences, 3, 67.

Blumenthal, S. (1954). The incidence of congenital cardiac malformations. Transactions of the American College of Cardiology, 3, 209.

Dawodu, A. H., Antia, A. U., and Lagundoye, S. B. (1972). Congenital aneurysm of the right pulmonary artery associated with persistent ductus arteriosus, ventricular septal defect and right-sided hypoplastic aorta. African fournal of Medical Sciences, 3, 241.

Gibson, S., and Clifton, W. M. (1938). Congenital heart disease. A clinical and post mortem study of 105 cases. American Fournal of Diseases of Children, 55, 761.

Keith, J. D., Rowe, R. D., and Vlad, P. (1958). Heart Disease in Infancy and Childhood, pp. 3, 6. MacMillan, New York.

MacMahon, B., McKeown, T., and Record, R. G. (1953). The incidence and life expectation of children with congenital heart disease. British Heart fournal, 15, 121.

Nadas, A. S. (1963). Pediatric Cardiology, 2nd ed., pp. 367, 399, 463. Saunders, Philadelphia.

Schrire, V. (1963). Experience with congenital heart disease at Groote Schuur Hospital, Cape Town. South African Medical Fournal, 37, 1175.

Wood, P. (1950). Congenital heart disease. British Medical Fournal, 2, 639.

Correspondence to Professor A. U. Antia, Department of Paediatrics, University College Hospital, Ibadan, Nigeria. 